\title{
Short communication: Effect of kefir grains on proteolysis of major milk proteins
}

\author{
I. M. P. L. V. O. Ferreira, ${ }^{* 1}$ O. Pinho, $†$ D. Monteiro, ${ }^{*}$ S. Faria, ${ }^{*}$ S. Cruz, ${ }^{*}$ A. Perreira, $\ddagger$ A. C. Roque, $\ddagger$ \\ and P. Tavares $\ddagger$ \\ ${ }^{*}$ REQUIMTE-Serviço de Bromatologia, Faculdade de Farmácia da Universidade do Porto, Rua Anibal Cunha 164, $4099-030$ Porto, Portugal \\ †Faculdade de Ciências da Nutrição e Alimentação da Universidade do Porto, Rua Dr. Roberto Frias, 4200-465 Porto, Portugal \\ ‡REQUIMTE-Faculdade de Ciências e Tecnologia, Universidade Nova de Lisboa, Caparica, Portugal
}

\section{ABSTRACT}

The effect of kefir grains on the proteolysis of major milk proteins in milk kefir and in a culture of kefir grains in pasteurized cheese whey was followed by reverse phase-HPLC analysis. The reduction of $\kappa-$, $\alpha-$, and $\beta$-caseins $(\mathrm{CN}), \alpha$-lactalbumin $(\alpha-\mathrm{LA})$, and $\beta$-lactoglobulin ( $\beta$-LG) contents during 48 and $90 \mathrm{~h}$ of incubation of pasteurized milk $(100 \mathrm{~mL})$ and respective cheese whey with kefir grains $\left(6\right.$ and $12 \mathrm{~g}$ ) at $20^{\circ} \mathrm{C}$ was monitored. Significant proteolysis of $\alpha-\mathrm{LA}$ and $\kappa_{-}, \alpha-$, and $\beta$-caseins was observed. The effect of kefir amount (6 and $12 \mathrm{~g} / 100 \mathrm{~mL}$ ) was significant for $\alpha-\mathrm{LA}$ and $\alpha-$ and $\beta$-CN. $\alpha$-Lactalbumin and $\beta$-CN were more easily hydrolyzed than $\alpha-\mathrm{CN}$. No significant reduction was observed with respect to $\beta$-LG concentration for 6 and $12 \mathrm{~g}$ of kefir in $100 \mathrm{~mL}$ of milk over $48 \mathrm{~h}$, indicating that no significant proteolysis was carried out. Similar results were observed when the experiment was conducted over $90 \mathrm{~h}$. Regarding the cheese whey kefir samples, similar behavior was observed for the proteolysis of $\alpha-\mathrm{LA}$ and $\beta$-LG: $\alpha$-LA was hydrolyzed between 60 and $90 \%$ after $12 \mathrm{~h}$ (for 6 and $12 \mathrm{~g}$ of kefir) and no significant $\beta$-LG proteolysis occurred. The proteolytic activity of lactic acid bacteria and yeasts in kefir community was evaluated. Kefir milk prepared under normal conditions contained peptides from proteolysis of $\alpha$-LA and $\kappa^{-}, \alpha-$, and $\beta$-caseins. Hydrolysis is dependent on the kefir:milk ratio and incubation time. $\beta$-Lactoglobulin is not hydrolyzed even when higher hydrolysis time is used. Kefir grains are not appropriate as adjunct cultures to increase $\beta$-LG digestibility in whey-based or whey-containing foods.

Key words: milk protein, high-performance liquid chromatography, kefir, proteolysis

Received June 19, 2009.

Accepted September 15, 2009.

${ }^{1}$ Corresponding author: isabel.ferreira@ff.up.pt
Kefir grains are small, gelatinous, yellowish, irregularly shaped masses resembling individual miniature cauliflower florets. In the kefir grains, lactic acid bacteria and yeasts are embedded in a slimy polysaccharide matrix, termed kefiran, which is produced by the lactobacilli in the grain. The grains contain a balance of microorganisms that exist in a complex symbiotic relationship. Various lactic acid bacteria and yeasts have been identified in kefir grains, including Lactobacillus brevis, Lactobacillus helveticus, Lactobacillus kefir, Leuconostoc mesenteroides, Kluyveromyces lactis, Kluyveromyces marxianus, and Pichia fermentans (Angulo et al., 1993; Lin et al., 1999; Simova et al., 2002; Corli Witthuhn et al., 2004). The main function of the microorganisms constituting the grains is the production of lactic acid, ethanol, peroxides, carbon dioxide, acetaldehyde, diacetyl and acetoin, antibiotics, and bactericide, which inhibit the development of pathogenic microorganisms in the kefir milk (Simova et al., 2002). Schmidt et al. (1984) reasoned that kefir, like yogurt, had a higher protein digestibility that contributed to its higher nutritional value.

The protein content of cow's milk is a complex mixture. About $80 \%$ of this mixture consists of $\mathrm{CN}$, which is a heterogeneous fraction subdivided into $\alpha-, \beta-$, and $\kappa-\mathrm{CN}$ in the proportions of 5:4:1, respectively. The remaining $20 \%$ of the milk protein fraction is composed of whey proteins, of which $\beta$-LG and $\alpha$-LA are the main components (ratio approximately 3:1). These proteins possess a relatively high content of essential AA and are an important source of bioactive sequences.

Cheese whey, a byproduct of the dairy industry, contains $\alpha-\mathrm{LA}$ and $\beta-\mathrm{LG}$, which account for its high nutritional value (Ferreira et al., 2007). Cheese whey fermentation by kefir could be a sensible solution for the use of this byproduct because hydrolysates of these proteins can be added to manufactured food for increased digestibility. However, the potential of kefir in the production of healthy products from cheese whey requires the evaluation of proteolysis. 
The proteolytic system of lactic acid bacteria $(\mathbf{L A B}$; lactococci and lactobacilli) is known to play an important role in milk proteolysis. The proteolytic system of lactococci has been a subject of biochemical and genetic research and the cell wall-bound proteinases have been divided into 2 main groups: the P1-type proteinases, which hydrolyze predominantly $\beta$-CN, and the PIII-type proteinases, which degrade $\alpha$ - and $\kappa$-caseins in addition to $\beta$-CN. The intermediate-type proteinases cleave $\beta-\mathrm{CN}$ in a manner similar to that of the $\mathrm{P} 1$ type but are also able to hydrolyze $\alpha_{\mathrm{S} 1}-\mathrm{CN}$ (Simova et al., 2002). In contrast to the lactococcal proteolytic system, limited information is available about the proteolytic system of lactobacilli. Proteolytic activity of Lactobacillus has been associated with cell wall-bound proteinases, as in the case of Lactococcus. The proteinase system most intensively studied is that of Lactobacillus casei. Although the action of each selected microorganism has been studied independently, few works have focused on the proteolytic activity of LAB and yeasts in kefir community (Kabadjova-Hristova et al., 2006).

The aim of the present study was to investigate the proteolytic activity of kefir grains in milk kefir and in a culture of kefir grains in pasteurized cheese whey, based on the reduction of $\kappa_{-}, \alpha-$, and $\beta$-caseins, $\alpha-L A$, and $\beta$-LG during kefir incubation. Milk proteins were evaluated by reverse phase-HPLC analysis.

All reagents used were of analytical-grade purity. Bovine milk CN [minimum purity of $75 \%$, determined by the Bradford method (Bradford, 1976)], purified $\alpha-$, $\beta-$, and $\kappa-\mathrm{CN}$ (minimum purity of 85,90 , and $80 \%$, respectively), and purified bovine standards of $\beta-\mathrm{LG}$ and $\alpha$-LA were supplied by Sigma Chemical Co. (St. Louis, MO). Casein, $\alpha-\mathrm{LA}$, and $\beta-\mathrm{LG}$ standard solutions were dissolved in a mixture of $70 \%$ of water and $30 \%$ of acetonitrile ( $\mathrm{vol} / \mathrm{vol}$ ). The solutions were stored at $-20^{\circ} \mathrm{C}$ until use.

Five samples of kefir grains were collected from households in northern Portugal. The numbers of viable counts of the lactococci, lactobacilli, and yeasts were determined in kefir grains when received at the laboratory. For this purpose, $10 \mathrm{~g}$ of each sample was collected aseptically into sterile sample bags (Whirl-Pak, Cole Parmer, Chicago, IL) and homogenized with sterile $2 \%$ (wt/vol) sodium citrate (Merck, Darmstadt, Germany) at $45^{\circ} \mathrm{C}$ [using a dilution factor $1: 10(\mathrm{vol} / \mathrm{vol})$ ] for $5 \mathrm{~min}$ in a Stomacher 400 Circulator (Seward, London, UK). Sequential decimal dilutions were prepared in sterile $0.1 \%$ (wt/vol) peptone water (Sigma Chemical Co.) and plated in duplicate. Lactococci and lactobacilli were grown anaerobically (Gas-Pak anaerobic system, BBL, Cockeysville, MD) on M17 agar (Lab M, Bury, $\mathrm{UK}$ ) and Rogosa agar (Lab M) at $30^{\circ} \mathrm{C}$ for 2 and $5 \mathrm{~d}$, respectively. Cycloheximide (Lab M) was added at a level of $100 \mathrm{mg} / \mathrm{L}$ to prevent growth of yeasts. Yeasts were grown on potato dextrose agar (Merck) acidified with $10 \%$ lactic acid at $25^{\circ} \mathrm{C}$ for $5 \mathrm{~d}$.

The traditional or artisanal method of making kefir is currently achieved by directly adding kefir grains $(2-10 \%)$ to milk that has been pasteurized and cooled to 20 to $25^{\circ} \mathrm{C}$. After a period of fermentation lasting approximately $24 \mathrm{~h}$, the grains are removed by filtration. The beverage, itself containing live microflora from the grain, is then ready for consumption. The traditional process of making kefir was carried out; however, the incubation period was extended to 48 and $90 \mathrm{~h}$.

The microbiological quality of pasteurized milk was safeguarded by cooling during transportation and storage. Rennet cheeses were prepared at the laboratory and whey was used to obtain cultures of kefir grains in cheese whey.

Five batches of pasteurized milk $(100 \mathrm{~mL})$ and 5 batches of cheese whey were inoculated with 6 and 12 $\mathrm{g}$ of kefir grains from households. All inoculated milk and cheese whey samples were incubated at $20^{\circ} \mathrm{C}$ for $48 \mathrm{~h}$, making a total of 20 samples. Additionally, blank samples of milk and cheese whey without kefir grains were prepared in the same conditions. One-milliliter aliquots were taken from each sample at $6,12,24,36$, and $48 \mathrm{~h}$ for HPLC analysis of $\alpha-, \beta$-, and $\kappa$-caseins, $\alpha$-LA, and $\beta$-LG. Prior to analysis by RP-HPLC, samples were diluted with ultra-purified water and filtered, and duplicate analyses were performed. All the experiments were repeated 2 wk later using a 90-h incubation time.

The chromatographic analysis was carried out in an analytical HPLC unit (Gilson, Middleton, WI) equipped with a type 305 pump, a type 302 pump, and a type 7125 Rheodyne Injector with a $20-\mu \mathrm{L}$ loop, a Gilson 118 variable longwave UV detector $(\lambda=215 \mathrm{~nm})$, and Gilson 712 HPLC system control software. Eluents for HPLC were filtered through $0.22-\mu \mathrm{m}$ NL 17 filters and degassed under vacuum for at least 15 min before use.

The column was a Chrompack P $300 \mathrm{RP}(8 \mu \mathrm{m}, 300$ A, $150 \times 4.6 \mathrm{~mm}$ i.d.; Palo Alto, CA). Gradient elution was carried out with a mixture of 2 solvents. Solvent A consisted of $0.1 \%$ trifluoroacetic acid in water and solvent B consisted of $0.1 \%$ trifluoroacetic acid in $95 \%$ aqueous acetonitrile (vol/vol). Proteins were eluted with a series of linear gradients: $0 \%$ of solvent B during $5 \mathrm{~min}$, from 0 to $5 \%$ of B over $4 \mathrm{~min}, 5$ to $15 \%$ of B over $6 \mathrm{~min}, 15$ to $33 \%$ of B over $10 \mathrm{~min}, 33$ to $40 \%$ of B over $6 \mathrm{~min}$, keeping this conditions during $6 \mathrm{~min}, 40$ to $50 \%$ of $\mathrm{B}$ over $8 \mathrm{~min}$, finishing with 50 to $0 \%$ of $\mathrm{B}$ in $5 \mathrm{~min}$, and $5 \mathrm{~min}$ for column reequilibration. The flow rate was $1.0 \mathrm{~mL} / \mathrm{min}$, the column was at room temperature, and the detection was made at a wavelength of $215 \mathrm{~nm}$.

The external standard method was used to calibrate the chromatographic system for the quantification of 
$\alpha-\mathrm{LA}, \beta-\mathrm{LG}$, and $\kappa_{-}, \alpha-$, and $\beta$-caseins. The detection limits were calculated as the concentration corresponding to 3 times the background noise of the blank. Standard solutions containing $0.1 \mathrm{mg} / \mathrm{mL}$ and $1.5 \mathrm{mg} /$ $\mathrm{mL}$ of each protein were used to evaluate the relative standard deviation of the method. A total of 12 analyses were performed for the 2 standard solutions.

The experimental recovery was obtained from the difference between 2 measurements (sample and spiked samples), according to the following relationship:

Recovery, $\%=($ total analyte found - analyte originally present $) \times 100 /$ analyte spike.

The concentrations of $\alpha-\mathrm{LA}, \beta-\mathrm{LG}$, and $\kappa^{-}, \alpha-$, and $\beta$-caseins in milk, cheese whey, milk kefir, and whey kefir were calculated by external standard method and expressed in milligrams per milliliter. The evolution of proteolysis was followed through the reduction of concentrations of $\alpha-\mathrm{LA}, \beta-\mathrm{LG}$, and $\kappa_{-}, \alpha-$, and $\beta$-caseins during kefir incubation and expressed as percentage of proteolysis.

Lactobacilli and lactococci contents of kefir grains presented accounts of $10^{9}$ and $10^{8} \mathrm{cfu} / \mathrm{mL}$, respectively. The yeast content of kefir grains ranged between $10^{6}$ and $10^{9} \mathrm{cfu} / \mathrm{mL}$. The microbial composition of the kefir grains depends on several factors, such as their origin, the cultivation and manufacturing methods, and the assay of microbial identification (Corli Witthuhn et al., 2004). Previous studies by Rea et al. (1996) indicated that Irish kefir grains contained $(\mathrm{cfu} / \mathrm{mL}) 10^{9}$ lactococci, $10^{6}$ lactobacilli, and $10^{6}$ yeasts, and studies performed by Guzel-Seydim et al. (2005) in Turkish kefir presented average accounts of 9.05 and $8.87 \log _{10}$ $\mathrm{cfu} / \mathrm{mL}$.

The external standard method was used to calibrate the chromatographic system for the quantification of $\alpha-\mathrm{LA}, \beta-\mathrm{LG}$, and $\kappa_{-}, \alpha-$, and $\beta$-caseins in milk and cheese whey. Linearity between the concentration of proteins and the UV absorbance at $215 \mathrm{~nm}$ was maintained over the concentration ranges of 0.01 to $1.5,0.04$ to 2.5 , and 0.02 to $3.06 \mathrm{mg} / \mathrm{mL}$, respectively, for $\alpha-\mathrm{LA}$, caseins, and $\beta$-LG. The correlation coefficient exceeded 0.999 for all proteins. Detection limits were 0.005, 0.02, and $0.01 \mathrm{mg} / \mathrm{mL}$, respectively.

The repeatability of peak areas was assessed by replicate injections $(\mathrm{n}=10)$ of a standard mixture of $\alpha$-LA, $\beta-\mathrm{LG}$, and $\kappa_{-}, \alpha_{-}$, and $\beta$-caseins at $0.1 \mathrm{mg} / \mathrm{mL}$ and $1.5 \mathrm{mg} / \mathrm{mL}$. The relative standard deviations were all below 4.12 and $1.88 \%$, respectively.

The areas under the most representative peaks on the chromatogram of diluted milk, designated $\alpha$-LA, $\kappa-\mathrm{CN}, \alpha-\mathrm{CN}, \beta-\mathrm{CN}$, and $\beta-\mathrm{LG}$, in order of elution, were used to study the evolution of the proteolytic process during incubation of milk and cheese whey with kefir grains (Figure 1). Peptide release was followed through peak formation in the chromatograms but not quantified. Casein peaks were characterized using caseins from bovine milk previously identified in our laboratory (Veloso et al., 2002). The reliability of the method was confirmed by 2 recovery experiments for an addition of $1.0 \mathrm{~g} / \mathrm{L}$ and $2.5 \mathrm{mg} / \mathrm{mL}$. Recoveries ranged between 88 and $96 \%$. Protein composition of pasteurized milk and respective cheese whey determined by RP-HPLC is presented in Table 1 . The results obtained for the major milk proteins were similar to literature values (Ferreira et al., 2001; Bramanti et al., 2002, 2003).

Significant proteolysis of $\alpha$-LA and $\alpha$ - and $\beta$-caseins occurred during milk incubation with kefir grains at $20^{\circ} \mathrm{C}$ for $48 \mathrm{~h}$, as presented in Figure 2. The effect of kefir amount (6 and $12 \mathrm{~g} / 100 \mathrm{~mL}$ ) was significant for $\alpha$-LA and $\alpha$ - and $\beta$-caseins $(P<0.05)$. $\alpha$-Lactalbumin and $\beta-\mathrm{CN}$ were more easily hydrolyzed than $\alpha-\mathrm{CN}$. After $12 \mathrm{~h}$ of incubation with 6 and $12 \mathrm{~g}$ of kefir grains in $100 \mathrm{~mL}$ of milk, no $\mathrm{\kappa}$-CN was detected in the chromatogram. The results obtained for $\alpha$ - and $\beta$-caseins are in agreement with other studies (Kabadjova-Hristova et al., 2006) that tested the ability of L. kefir DR22x, a Lactobacillus species frequently present in kefir grains, to hydrolyze $\alpha-, \beta-$, and total caseins after induction of the proteinases in de Man, Rogosa, and Sharpe bacterial growth medium supplemented with 5\% milk. In this case, the crude proteinase extract obtained predominantly hydrolyzed $\beta$-CN by washing the cells in a buffer free of $\mathrm{Ca}^{2+}$. $\alpha$-Casein and total $\mathrm{CN}$ were weakly hydrolyzed; however, the proteolytic activity of the whole cells was higher than that of the cell wall extract.

Concerning proteolysis of $\alpha$-LA, no references were found for kefir proteolysis; however, this protein was hydrolyzed by kefir grains (Figure 2). Bertrand-Harb et al. (2003) studied the evolution of the concentrations of $\beta-L G$ and $\alpha$-LA during the early stages of yogurt fermentation by a mixed strain culture containing Streptococcus thermophilus and Lactobacillus delbrueckii ssp. bulgaricus. Samples taken at different times indicated that the concentration of both proteins remained constant during fermentation. In model experiments, the strains were incubated either separately or in combination with both whey proteins, one by one or together. $\alpha$-Lactalbumin was susceptible to proteolysis, whereas $\beta$-LG proteolysis required a longer time than that used during yogurt fermentation.

No significant reduction was observed with respect to $\beta$-LG concentration for 6 and $12 \mathrm{~g}$ of kefir in 100 $\mathrm{mL}$ of milk; the concentration remained almost constant during $48 \mathrm{~h}$, indicating that no significant hydrolysis $(P$ 
Table 1. Protein composition of pasteurized milk and respective cheese whey expressed as $\mathrm{mg} / \mathrm{mL}$ (mean value of duplicate assays)

\begin{tabular}{lccccc}
\hline Sample & $\alpha$-LA & $\kappa$-CN & $\alpha$-CN & $\beta$-CN & $\beta$-LG \\
\hline Pasteurized milk & 1.55 & 2.91 & 12.43 & 9.11 & 3.26 \\
Cheese whey & 1.23 & ND $^{1}$ & 0.62 & 0.71 & 3.13 \\
\hline
\end{tabular}

${ }^{1} \mathrm{ND}=$ not detected.

$>0.05)$ was carried out. Thus, another experiment was conducted for a period of $90 \mathrm{~h}$, but similar results were obtained. The most prevalent protein in cheese whey is $\beta$-LG (Ferreira and Caçote, 2003). The proteolysis of $\beta$-LG by microorganisms is difficult, as observed by other study (Bertrand-Harb et al., 2003), probably because the molecular structure contains 2 disulfide bonds.

Concerning the whey kefir samples, similar behavior was observed for $\alpha-\mathrm{LA}$ and $\beta-\mathrm{LG}$ proteolysis: $\alpha-\mathrm{LA}$ was hydrolyzed between 60 and $90 \%$ after $12 \mathrm{~h}$ (for 6 and 12 $\mathrm{g}$ of kefir) and no significant $\beta$-LG proteolysis occurred. As expected, the CN content of cheese whey was low and no $\mathrm{CN}$ was quantified after $6 \mathrm{~h}$ of incubation. Other authors studied the ability of 3 LAB strains (Lactobacillus delbrueckii ssp. bulgaricus CRL 454, Lactobacillus acidophilus CRL 636, and Streptococcus thermophilus CRL 804) to hydrolyze $\beta-\mathrm{LG}$ and $\alpha$-LA in a culture medium supplemented with these proteins or whey protein concentrate (Pescuma et al., 2007). These authors evaluated protein hydrolysis by tricine SDS-PAGE and RP-HPLC. Maximum $\beta$-LG (21\%) and $\alpha$-LA (26\%) degradation by $\mathrm{LAB}$ was observed using whey protein concentrate (Pescuma et al., 2007). However, it should be pointed out that this does not correspond to real kefir incubation conditions.

The results presented in this work contribute to the understanding of the proteolytic activity of kefir grains in milk kefir and in a culture of kefir grains in pasteurized cheese whey and the protein digestibility of these biocultures of kefir grains. Under normal conditions of preparation of kefir milk, it contains peptides derived from the proteolysis of $\alpha-\mathrm{LA}$ and $\alpha-, \beta$-, and $\kappa$-caseins. Hydrolysis is dependent on the kefir:milk ratio and incubation time. Further studies on characterization of peptides and amino acids formed after hydrolysis will be undertaken. $\beta$-Lactoglobulin is not hydrolyzed even when long hydrolysis time and high kefir amounts are used. These results suggest that kefir grains are not appropriate as adjunct cultures to increase $\beta-\mathrm{LG}$ digestibility in whey-based or whey-containing foods.

\section{ACKNOWLEDGMENTS}

This work was supported by the project REQSEP from Rede Química e Tecnologia (REQUIMTE).

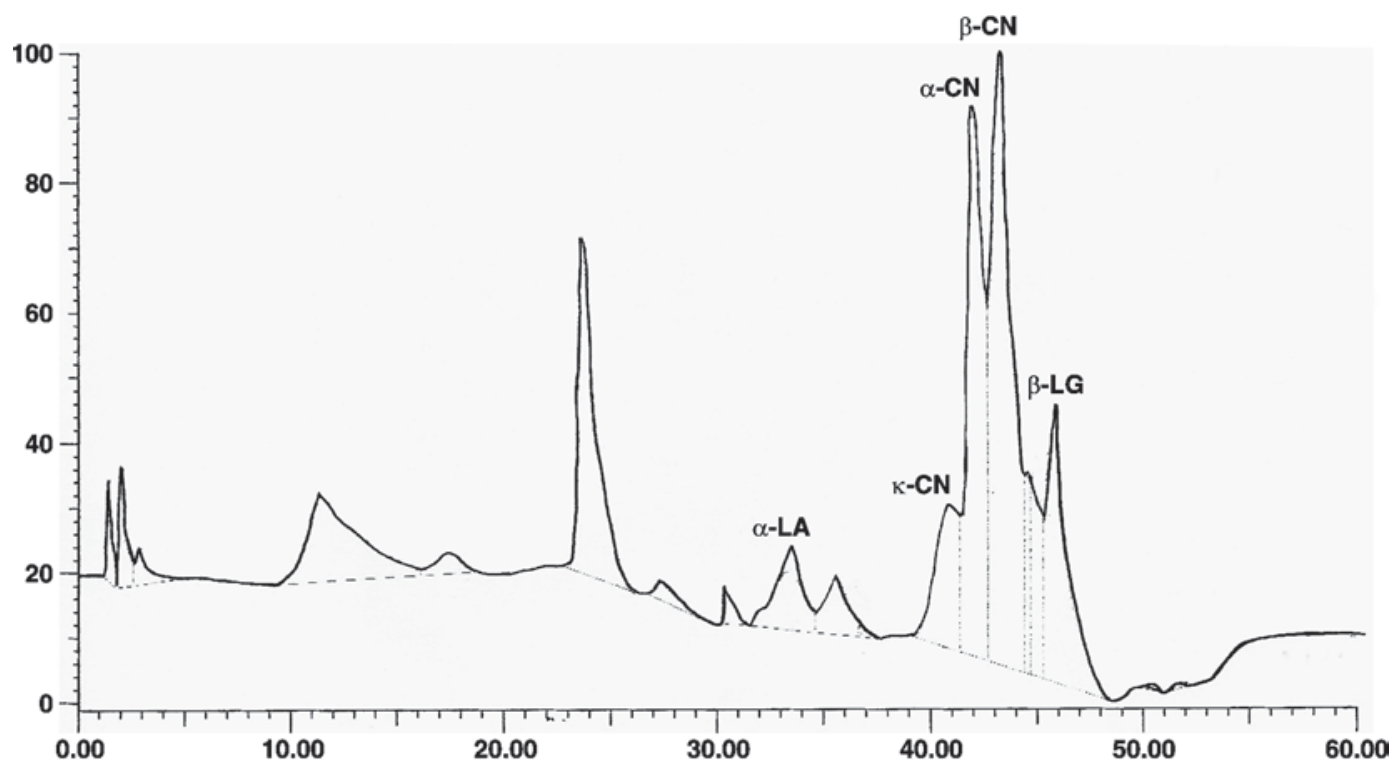

Figure 1. Typical chromatographic profile of $12 \mathrm{~g}$ of milk kefir undergoing a 6-h hydrolysis (chromatographic conditions described in the text): $\alpha$-LA $(0.45 \mathrm{mg} / \mathrm{mL}), \kappa-\mathrm{CN}(1.31 \mathrm{mg} / \mathrm{mL}), \alpha-\mathrm{CN}(8.70 \mathrm{mg} / \mathrm{mL}), \beta-\mathrm{CN}(5.46 \mathrm{mg} / \mathrm{mL})$, and $\beta-\mathrm{LG}(3.14 \mathrm{mg} / \mathrm{mL})$. 


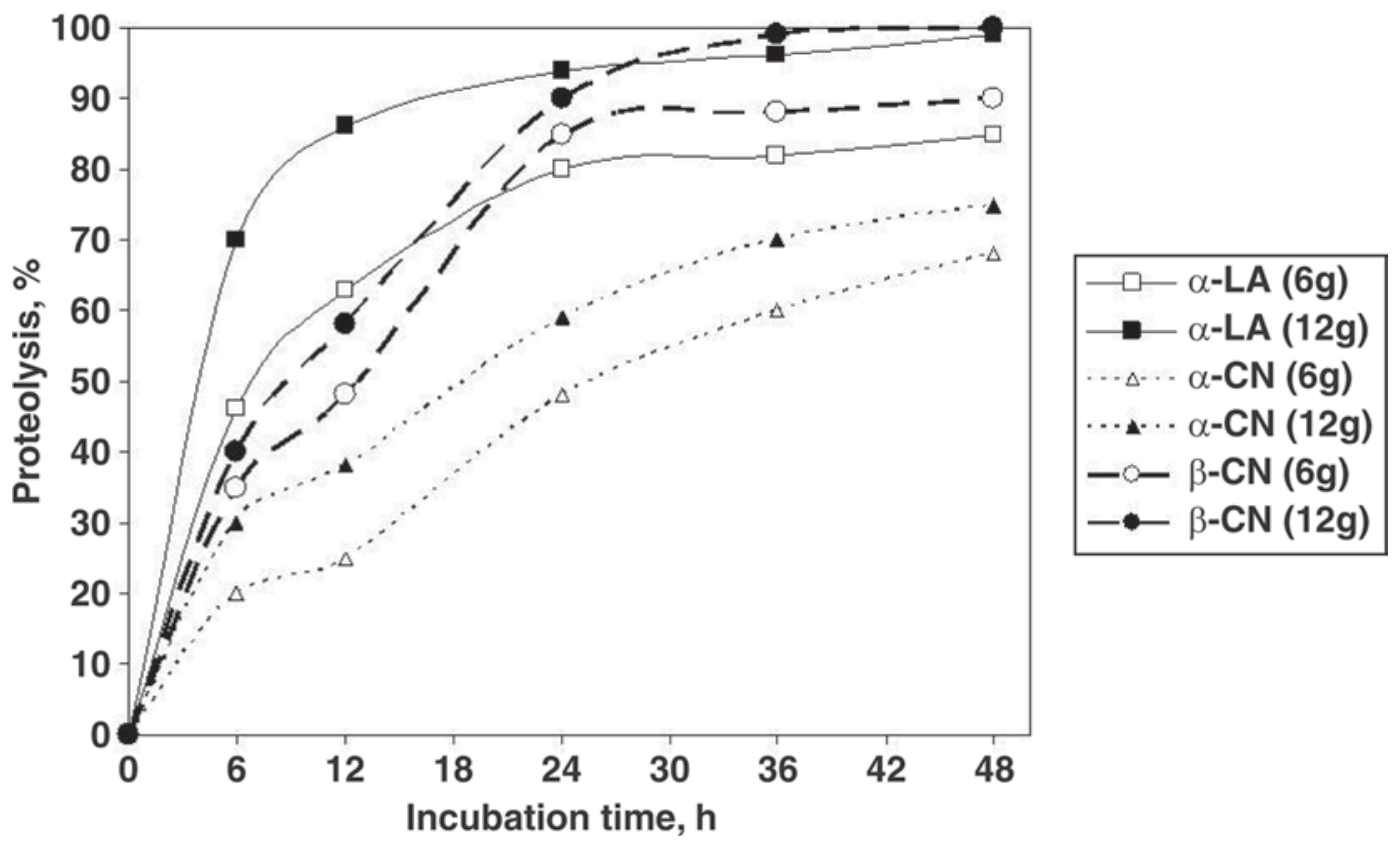

Figure 2. The evolution of proteolysis of $\alpha-\mathrm{CN}, \beta-\mathrm{CN}$, and $\alpha$-LA, expressed as proteolysis percentage during $48 \mathrm{~h}$ of milk kefir (6 g and 12 $\mathrm{g} / 100 \mathrm{~mL}$ ) incubation. Each point represents the mean value obtained for 5 kefir samples (SD for all values was approximately $\pm 5 \%$ in most cases).

\section{REFERENCES}

Angulo, L., E. Lopez, and C. Lema. 1993. Microflora present in kefir grains of the Galician region (north-west of Spain). J. Dairy Res. 60:263-267.

Bertrand-Harb, C., I. V. Ivanova, M. Dalgalarrondo, and T. Haertlle. 2003. Evolution of $\beta$-lactoglobulin and $\alpha$-lactalbumin content during yogurt fermentation. Int. Dairy J. 13:39-45.

Bradford, M. M. 1976. A rapid and sensitive method for quantitation of microgram quantities of protein utilizing the principle of proteindye binding. Anal. Biochem. 72:248-254.

Bramanti, E., C. Sortino, M. Onor, F. Beni, and G. Raspi. 2003. Separation and determination of denatured $\alpha$ s1- $\alpha$ s2-, $\beta-$ and $\kappa$-caseins by hydrophobic interaction chromatography in cows', ewes' and goats' milk, milk mixtures and cheeses. J. Chromatogr. A 994:59-74.

Bramanti, E., C. Sortino, and G. Raspi. 2002. New chromatographic method for separation and determination of denatured os1- as2-, $\beta$ - and $\kappa$-caseins by hydrophobic interaction chromatography. J. Chromatogr. A 958:157-166.

Corli Witthuhn, R., T. Schoeman, and T. Britz. 2004. Isolation and characterization of the microbial population of different South African kefir grains. Int. J. Dairy Technol. 57:33-37.

Ferreira, I. M. P. L. V. O., and H. Caçote. 2003. Detection and quantification of bovine, ovine and caprine milk percentages in protected denomination of origin cheeses by reversed-phase highperformance liquid chromatography of beta-lactoglobulins. J. Chromatogr. A 1015:111-118.

Ferreira, I. M. P. L. V. O., E. Mendes, and M. A. Ferreira. 2001. HPLC/ UV analysis of proteins in dairy products using a hydrophobic interaction chromatographic column. Anal. Sci. 17:499-501.

Ferreira, I. M. P. L. V. O., O. Pinho, M. V. Mota, P. Tavares, A. Pereira, M. P. Gonçalves, D. Torres, C. Rocha, and J. A. Teixeira.
2007. Preparation of ingredients containing an ACE-inhibitory peptide by tryptic hydrolysis of whey protein concentrates. Int. Dairy J. 17:481-487.

Guzel-Seydim, Z., J. Twyffels, A. C. Seydim, and A. K. Greene. 2005. Turkish kefir and kefir grains: Microbial enumeration and electron microscobic observation. Int. J. Dairy Technol. 58:25-29.

Kabadjova-Hristova, P., S. Bakalova, B. Gocheva, and P. Moncheva. 2006. Evidence for proteolytic activity of lactobacilli isolated from kefir grains. Biotechnol. Biotechnol. Equip. 20:89-94.

Lin, C. W., C. L. Chen, and J. R. Liu. 1999. Identification and characterisation of lactic acid bacteria and yeasts isolated from kefir grains in Taiwan. Aust. J. Dairy Technol. 54:14-18.

Pescuma, M., E. M. Hébert, F. Mozzi, and G. F. Valdez. 2007. Hydrolysis of whey proteins by Lactobacillus acidophilus, Streptococcus thermophilus and Lactobacillus delbrueckii ssp. bulgaricus grown in a chemically defined medium. J. Appl. Microbiol. 103:1738-1746.

Rea, M. C., T. Lennartsson, P. Dilon, F. D. Drinan, W. J. Reville, M. Heapes, and T. M. Cogan. 1996. Irish kefir like grains: Their structure, microbial composition and fermentation kinetics. J. Appl. Bacteriol. 81:83-84.

Schmidt, P., A. Vass, and S. Szakaly. 1984. Effect of fermented milk diets on regeneration of rat liver. Acta Med. Hung. 41:163-169.

Simova, E., D. Beshkova, A. Angelov, T. S. Hristozova, G. Frengova, and Z. Spasov. 2002. Lactic acid bacteria and yeasts in kefir grains and kefir made from them. J. Ind. Microbiol. Biotechnol. 28:16 .

Veloso, A. C., N. Teixeira, and I. M. P. L. V. O. Ferreira. 2002. Separation and quantification of the major casein fractions by reversed-phase high-performance liquid chromatography and ureapolyacrylamide gel electrophoresis. Detection of milk adulterations. J. Chromatogr. A 967:209-218. 